\title{
PENGARUH KEPEMIMPINAN DAN BUDAYA ORGANISASI TERHADAP KINERJA SDM PADA YAYASAN BAITURRAHMAN SURABAYA
}

\author{
Ahmad Nofal Abudi \\ STID Al-Hadid, Surabaya \\ nofalabudi88@gmail.com
}

\begin{abstract}
Abstrak: Pada era globalisasi seperti sekarang ini tantangan organisasi dakwah demikian besar, maka menjadi penting SDM organisasi dakwah memiliki kinerja yang tinggi dan mampu melewati tantangan zaman. Berdasarkan penelitian beberapa ilmuwan selama ini, variabel kepemimpinan dan budaya organisasi merupakan dua variabel yang mempengaruhi kinerja SDM suatu organisasi. Sedangkan peningkatan kinerja Pengurus baru Yayasan Baiturrahman, yang diiringi oleh perubahan type kepemimpinan oleh pemimpin yang baru dan munculnya budaya organisasi baru, menarik untuk dilakukan studi lebih lanjut. Tujuan studi ini menganalisis pengaruh variabel kepemimpinan dan budaya organisasi terhadap kinerja SDM pengurus yayasan Baiturrahman Surabaya. Kerangka teoritis dikembangkan dari konsep pengukuran kinerja SDM berdasarkan perilaku, kepemimpinan transformasional, dan budaya organisasi. Menggunakan pendekatan kuantitatif, dengan sumber data keseluruhan pengurus sejumlah 25 orang, yang kesemuanya telah diambil sebagai responden. Teknik analisis yang digunakan dalam penelitian adalah metode analisis regresi linier berganda. Data yang dianalisis berasal dari penyebaran kuesioner kepada pengurus (responden). Hasilnya menunjukkan bahwa secara parsial variabel kepemimpinan berpengaruh positif dan signifikan terhadap kinerja SDM pengurus. Sedangkan budaya organisasi yayasan Baiturrahman Surabaya telah terbukti memberikan pengaruh signifikan tetapi bernilai negatif terhadap kinerja SDM pengurus Yayasan. Sedangkan kedua variabel tersebut (kepemimpinan dan budaya organisasi) berpengaruh signifikan secara simultan terhadap kinerja SDM pengurus yayasan Baiturrahman Surabaya.

Kata kunci: kinerja SDM, kepemimpinan transformasional, budaya organisasi, organisasi dakwah
\end{abstract}

\begin{abstract}
Abstrak: In this globalization era, the challenges of $d a^{\prime}$ wah organization are enormous. Therefore, it is essential for human resources of da'wah organization to have high work performance and being able to deal with the era's challenges. Based on several researches from scientists, variables of leadership and organizational culture constitute the ones which influence work performance of human resources in an organization. The improvement of work performance of new human resources in the foundation of Baiturrahman, which is in line with the change of leadership type by new leader and the existence of new organizational culture, is interesting to be studied further. The study aims to analyze the influence of variables of leadership and organizational culture towards the work performance of human resources in the foundation of Baiturrahman Surabaya. The theoritical frame is developed from the concept of measuring the work performance of human resource based on behavior, transformational leadership, and organizational culture. The study uses quantitative approach, with the data source of complete number of committees which numbers 25 people. All of the people have participated as respondents. Analysis technique used in the research is double linear regressive analysis. Analyzed data originated from the share of questionnaires to the committees (respondents). The result
\end{abstract}


indicates that the variable of leadership partially provides positive and significant influence towards the work performance of committees. Meanwhile, organizational culture of the foundation of Baiturrahman Surabaya has been proven to give significant influence but negative towards human resources of the foundation's committees. Those two variables (leadership and organizational culture) affect simultaneously significant towards human resources of the foundation's committees. Keywords: work performance of human resource, transformational leadership, organizational culture, da'wah organization

\section{Pendahuluan}

Seorang muslim yang mendakwahkan ajaran Islam, baik itu menyeru kepada kebaikan ataupun melarang keburukan akan lebih baik jika bekerjasama dalam suatu organisasi dakwah. Banyak tantangan yang siap menghadang di era globalisasi seperti sekarang. Contoh dari salah sat tantangan yang dihadapi generasi muda saat ini adalah banyaknya hiburan-hiburan yang melanggar norma - norma Islam, bahkan berdampak rusaknya moral generasi muda. Implikasi dari dari hal ini jika menjadi suatu kultur, maka bangsa Indonesia mengarah pada budaya pragmatisme, materialisme, dan hedonisme. Keadaan ini menjadi tantangan yang berat bagi dakwah. Nilai-nilai yang didakwahkan para dai akan bersaing secara langsung dengan budaya pragmatisme, materialisme, dan hedonisme.

Tantangan seperti di atas membutuhkan energi besar dan tekad bulat dalam berdakwah. Pada keadaan seperti ini dibutuhkan kinerja yang berkualitas dari SDM organisasi dakwah. Ketika SDM organisasi dakwah tidak berkinerja baik maka akan mustahil bagi organisasi tersebut untuk bisa sukses dalam misi dakwahnya. Belum lagi ada persoalan organisasi menghadapi para pesaingnya baik sesama

\footnotetext{
1 Locander, Hamilton, Ladik \&Stuart, "Developing a Leadership-Rich Culture," 153. Locander, W.B., F. Hamilton, D. Ladik \& J. Stuart. "Developing a Leadership-Rich Culture: The Missing Link to Creating
}

organisasi dakwah atau dari agama lain. Dengan SDM organisasi dakwah yang memiliki kualitas kinerja baik, maka organisasi dakwah dapat terus bertahan dan tidak hancur akibat kompetisi. Bahkan, organisasi dakwah akan mampu berkembang serta mencapai tujuannya dengan kualitas kinerja SDM yang baik

Selanjutnya penting untuk mengetahui bagaimana cara meningkatkan kinerja SDM suatu organisasi, khususnya organisasi dakwah. Bila melihat relasi antara SDM pada suatu organisasi yang saling bekerjasama untuk merealisasikan tujuan bersama dengan panduan seorang pemimpin organisasi. Maka hipotesa dalam studi ini bahwa variabel kepemimpinan dalam suatu organisasi akan memengaruhi kinerja SDM di dalam organisasi tersebut.

Konsep kepemimpinan yang cukup populer diantaranya adalah konsep kepemimpinan transaksional dan tranformasional yang dikenalkan oleh Bass pada tahun $1985 .{ }^{1}$ Kedua konsep tersebut berbasiskan pada gaya, perilaku serta situasi yang meliputi seorang pemimpin. ${ }^{2}$ Kepemimpinan tranformasional berpijak pada prinsip pengembangan bawahan (follower development). Pemimpin mengembangkan

a Market-Focused Organization," Journal of MarketFocused Management, Vol. 5, 2002.

2 Ibid., 155. 
serta mengarahkan potensi ataupun kemampuan bawahan untuk mencapai hingga melampaui tujuan organisasi. ${ }^{3}$

Adapun faktor penting yang dipandang mempengaruhi kinerja karyawan diantaranya adalah budaya organisasi. ${ }^{4}$ Budaya organisasi merupakan suatu nilainilai bersama dan norma-norma perilaku yang diyakini serta dianut oleh anggota anggota organisasi ${ }^{5}$. Hipotesa studi ini bahwa budaya organisasi akan memengaruhi kinerja SDM organisasi tersebut, dikarenakan SDM dalam organisasi tersebut memiliki nilai dan norma dari budaya organisasi yang akan menjadi pijakan SDM organisasi tersebut dalam melakukan pekerjaannya.

Penelitian yang dilakukan oleh Bass, ${ }^{6}$ Locander, ${ }^{7}$ serta Yammarino, ${ }^{8}$ menemukan kepemimpinan (leadership) merupakan faktor penentu dari kinerja sumber daya manusia serta kemampuan organisasi saat beradaptasi dengan perubahan lingkungan. Kepemimpinan memberikan gambaran hubungan pemimpin (leader) dengan yang dipimpin (follower) dan cara seorang

${ }^{3}$ T. Dvir, D. Eden, B.J. Avolio \& B. Shamir,"Impact of Transformational Leadership on Follower Development and Performance: A Field Experiment," Academy of Management Journal, Vol. 45, No. 4, (2002), 736.

4 Gibson, Ivancevich, dan Donnelly,Organizations: Organisasi, perilaku, struktur, proses, Alih bahasa NunukArdiani, (Jakarta: Binarupa aksara, Jakarta, 1996), 43.

5 D.G. Harber, N.M. Ashkanasy \& V.J. Callan, "Implementing Quality Service in a Public Hospital Setting: a Path-Analytic Study of the Organizational Antecedents of Employee Perceptions and Outcomes" Public Productivity \& Management Review, Vol. 21, No. 1, (1997), 15.

6 B.M. Bass, B.J. Avolio, D.I. Jung \& Y. Berson, "Predicting Unit Performance by Assessing Transformational and Transactional Leadership," Journal of Applied Psychology, Vol. 88, No. 2, (2003), 209. pemimpin mengarahkan pengikutnya dan akan menentukan sejauh mana pengikutnya telah mencapai tujuan atau harapan pemimpin. Sedangkan Ogbonna dan Harris meneliti terkait gaya kepemimpinan, ${ }^{9}$ budaya organisasi dan kinerja di beberapa perusahaan United Kingdom. Pada hasil penelitian tersebut ditemukan bahwa gaya kepemimpinan tidak memiliki hubungan secara langsung dengan kinerja. Namun terkait hubungan budaya kompetitif dengan inovatif serta kinerja organisasi ditemukan ada hubungan positif dan kuat. Selain itu ada penelitiannya Desphande \& Farley, ${ }^{10}$ terkait budaya organisasi, orientasi pasar, inovasi, dan kinerja perusahaan di beberapa negara Asia dan Eropa, hasil penelitian tersebut menjelaskan bahwa budaya organisasi, orientasi pasar, serta inovasi memiliki pengaruh positif terhadap kinerja perusahaan. Berpijak pada penelitianpenelitian tersebut di atas, ternyata ada potensi hubungan serta pengaruh kepemimpinan dan budaya organisasi terhadap suatu kinerja SDM organisasi.

Studi ini meneliti pada Yayasan Baiturrahman Surabaya yang beralamat Jl.

\footnotetext{
7 W.B. Locander, F. Hamilton, D. Ladik \& J. Stuart, "Developing a Leadership-Rich Culture: the Missing Link to Creating a Market-Focused Organization," Journal of Market-Focused Management, Vol. 5, (2002), 150.

8 F.J. Yammarino, W.D. Spangler \& B.M. Bass (1993), "Transformational Leadership and Performance: A longitudinal Investigation,"Leadership Quarterly, Vol. 4, No. 1, (1993), 83.

9 E. Ogbonna \& L.C. Harris, "Leadership Style, Organizational Culture and Performance: Empirical Evidence from UK Companies," International Journal of Human Resource Management, Vol. 11, No. 4, (2000), 767.

${ }^{10}$ R. Deshpande \& J. Farley, "Executive Insights: Corporate Culture and Market Orientation: Comparing Indian and Japanese Firms," Journal of International Marketing, Vol. 7, No. 4, (1999), 112.
} 
Juwingan nomor 1B Surabaya. Yayasan ini tercatat pada akta notaris Ariyani, S.H., nomor 27 tanggal 15 September 2010, meski sudah berdiri sejak tanggal $16 \mathrm{Mei}$ 1963 namun karena sesuatu hal maka dilakukan pembaharuan akta notaris Yayasan. Yayasan ini bergerak pada bidang pendidikan, kemasjidan dan sosial. Pada bidang pendidikan, Yayasan Baiturrahman Surabaya mengelola pendidikan mulai TK, SD atau juga biasa disebut Madrasah Ibtidaiyah, SMP, serta SMA.

Sejarah pendirian yayasan ini dilatar belakangi penyerobotan sebagian tanah di Juwingan yang dimiliki oleh keluarga Baswedan (pemilik tanah dibanyak area Surabaya dari suku Arab) oleh orang-orang Partai Komunis Indonesia pada sekitar tahun 1960-an. maka semenjak orang-orang PKI bisa diusir oleh warga setempat, maka tanah yang memiliki luas $8600 \mathrm{~m}^{2}$ dihibahkan kepada pengurus Yayasan Baiturrahman sebagai perwakilan warga muslim Juwingan. Setelah proses hibah itu, maka segera warga muslim Juwingan saling membantu untuk membangun masjid yang kemudian diberi nama Masjid Baiturrahman. Begitulah proses berdirinya Yayasan Baiturrahman.

Bagi peneliti ada sesuatu yang menarik dijadikan sebagai subjek studi pada yayasan ini yaitu mulai berdiri hingga awal tahun 2010 pengurus Yayasan Baiturrahman Surabaya tidak aktif. Namun saat periode kepengurusan baru di tahun 2010, maka berjalannya Pengurus Yayasan Baiturrahman mulai terlihat serta dinamika aktivitas program yayasan sudah jalan. Realitas kepemimpinan yang diamati dalam kepengurusan Yayasan Baiturrahman yang baru lebih cenderung memenuhi indikator kepemimpinan transformasional dengan menunjukkan karakter lebih berorientasi kepada individu pengurus, tidak hanya fokus mengejar target program yayasan tetapi juga melakukan pendekatan personal/dialog dengan pengurus dan memecahkan masalah mereka secara individual. Fenomena ini bisa dilihat antara lain, ketika ada divisi atau unit pelaksana teknis misalnya Kepala Sekolah TK Baiturrahman yang kelihatan programnya tidak ada progress dari triwulan sebelumnya, maka Ketua Yayasan Baiturrahman mengajak dialog Kepala Sekolah TK Baiturrahman tersebut, misalnya ada kendala yang dialami, sebisa mungkin Ketua Yayasan Baiturrahman membantu pemecahan masalahnya, bahkan Ketua Yayasan mau meminjamkan uang kepada Kepala Sekolah TK tersebut agar pelaksanaan program bisa berjalan lancar. Jika ada kendala yang cukup besar, misalnya yang dihadapi oleh divisi takmir masjid dalam mengelola parkir masjid, maka ketua mengumpulkan seluruh pengurus dan stakeholder yang terkait dengan masalah itu untuk memusyawarahkan masalah tersebut sehingga tercapai kesepakatan, adanya aturan yang disepakati antara pemilik mobil dan divisi takmir sehingga program takmir dan Sekolah yang sama- sama menggunakan lahan parkir masjid bisa berjalan dengan lancar.

Adanya kepemimpinan dan kepengurusan yang baru, membuat Yayasan Baiturahman dapat menjalankan program satu demi satu sesuai perencanaan, dan keberadaan pengurus yayasan bisa mulai dirasakan badan usaha atau unit pelaksana teknis yang berada di bawah Yayasan Baiturrahman Surabaya. Tentunya kepengurusan baru yayasan ini akan berdampak pada 
perbedaan budaya organisasi antara saat pengurus baru dan lama. Cara interaksi dalam pola kepemimpinan Ketua Yayasan Baiturrahman ternyata memunculkan budaya guyub di antara para pengurus dan pengelola unit usaha Yayasan Baiturrahman. Sifat guyub ini yang diistilahkan oleh Cameron \& Quinn dalam Buku yang ditulis Herry Tjahyono sebagai clan culture yang memiliki indikasi karakter kekeluargaan amat menonjol, kepemimpinan akan memediasi segala konflik dalam organisasi, dan partisipasi karyawan amat ditekankan. ${ }^{11}$ Indikasi ini bisa diamati pada fenomena di Yayasan Baiturrahman pada kepengurusan yang baru, misalkan ada SDM yang mengalami kesulitan, maka mereka akan membagi masalah mereka kepada pengurus yang lain, terutama kepada Ketua Yayasan Baiturrahman dan yang lain akan berupaya mencari tahu mendengarkan masalah rekan sesama pengurus. Secara bersama Ketua Yayasan dan pengurus yang mengetahui masalah tersebut berupaya membantu pengurus yang memiliki masalah tersebut. Berdasarkan paparan mengenai aspek kepemimpinan dan budaya di atas, bisa disimpulkan secara indikasi awal, ada upaya dari Ketua pengurus Yayasan Baiturrahman untuk meningkatkan kinerja pengurus supaya yang meningkat kinerjanya dibandingkan dengan pengurus sebelumnya dengan pendekatan kepemimpinan dan sekaligus pendekatan budaya.

Berpijak latar belakang tersebut, dapat diidentifikasi adanya perubahan kinerja pengurus Yayasan, namun hasil kinerja itu apa akibat pengaruh variabel kepemimpinan ataukah budaya organisasi

${ }^{11}$ Tjahyono, Herry, Culture Based Leadership: Menuju Kebesaran Diri \& Organisasi Melalui Kepemimpinan juga memiliki peran dalam mempengaruhi kinerja pengurus yayasan. Dengan demikian permasalahan yang didalami adalah studi ini adalah menguji hipotesa bahwa budaya organisasi dan kepemimpinan apakah menjadi faktor yang berpengaruh terhadap kinerja sumber daya manusia pengurus Yayasan Baiturrahman Surabaya. Sehingga fokus dari tulisan ini antara lain: (a) apakah kepemimpinan (transformasional) memiliki pengaruh terhadap kinerja pengurus Yayasan Baiturrahman Surabaya? (b) apakah budaya organisasi memiliki pengaruh terhadap kinerja pengurus Yayasan Baiturrahman Surabaya? dan (c) Apakah kepemimpinan (transformasional) dan budaya organisasi memiliki pengaruh secara simultan pada kinerja pengurus Yayasan Baiturrahman Surabaya?

Orientasi umum tulisan ini antara lain untuk menganalisis faktor-faktor yang mempengaruhi terhadap kinerja Pengurus Yayasan Baiturrahman Surabaya. Sedangkan orientasi khususnya adalah: menganalisis pengaruh kepemimpinan (transformasional) terhadap kinerja Pengurus Yayasan Baiturrahman Surabaya; (b) menganalisis pengaruh budaya organisasi terhadap kinerja Pengurus Yayasan Baiturrahman Surabaya; (c) menganalisis pengaruh kepemimpinan (transformasional) dan budaya organisasi secara simultan terhadap Pengurus Yayasan Baiturrahman Surabaya.

Pada penelitian-penelitian sebelumnya, seperti pada penelitian yang dilakukan

Berbasiskan Budaya dan Budaya Kinerja Tinggi, (Jakarta: PT. Gramedia Pustaka Tama, Jakarta: 2010). 
Humphreys (2002), ${ }^{12}$ penelitian ini dalam konteks lingkup industri jasa menjelaskan bahwa kepemimpinan trasnformasional memiliki pengaruh yang penting dalam meningkatkan kinerja SDM salesnya. Penelitian yang dilakukan Bono dan Judge (2003), ${ }^{13}$ secara empirik juga membuktikan kinerja karyawan dipengaruhi kepemimpinan transformasional. Penelitian Bono dan Judge mengukur kinerja dari dari banyak aspek (sifatnya objektif ataupun subjektif) sehingga mereka berkesimpulan kinerja karyawan akan dipengaruhi kepemimpinan transformasional dalam semua keadaan. Dan penelitian yang dilakukan oleh Desphande \& Farley ${ }^{14}$ tentang budaya organisasi, orientasi pasar, inovasi dan kinerja perusahaan pada beberapa negara di Asia dan Eropa, hasil penelitiannya menunjukan bahwa budaya organisasi, orientasi pasar dan inovasi memiliki pengaruh positif pada kinerja perusahaan. Berdasarkan beberapa penelitian di atas, maka ada potensi kinerja SDM organisasi memiliki hubungan serta dipengaruhi oleh kepemimpinan dan budaya organisasi.

\section{Pengukuran Kinerja SDM}

Kata kinerja diambil dari istilah job performance atau istilah lainnya actual performance yang berarti prestasi kerja atau capaian prestasi riel oleh seseorang karyawan. Kinerja SDM atau job

12 J.H. Humphreys, "Transformational Leader Behavior, Proximity and Successful Services Marketing," Journal of Services Marketing, Vol. 16, No. 6, (2002), 490.

${ }^{13}$ Bono, J.E. \& T.A. Judge. "Self-Concordance at Work: Toward Understanding the Motivational Effects of Transformational Leaders," Academy of Management Journal, Vol. 46, No. 5, (2003), 554-571.

${ }^{14}$ R. Deshpande \& J. Farley, "Executive Insights: Corporate Culture and Market Orientation: performance memiliki pengertian kualitas dan kuantitas pelaksanaan tanggung jawab maupun tugas kerja dari seseorang. ${ }^{15}$ Sedangkan pada tulisan ini akan menggunakan salah satu teknik pengukuran kinerja SDM yang dikemukakan oleh Stephen P. Robbins \& Judge Timothy A. Hal ini dikarenakan salah satu teknik pengukuran yang dikemukakan oleh Stephen P. Robbins \& Judge Timothy A. cukup mudah untuk diteliti dalam suatu aktivitas organisasi, serta tentunya aspek rasionalitas, bisa dipertanggungjawabkan bahwa aspek perilaku tersebut bisa dijadikan alat ukur mengukur kinerja seorang SDM di suatu organisasi. Pada penelitian ini teknik pengukuran tersebut dioperasionalkan dalam bentuk angket terhadap pengurus Yayasan Baiturrahman.

Robbins \& Timothy juga menyampaikan ada tiga kriteria saat mengukur kinerja karyawan, yaitu: ${ }^{16}$ pengukuran didasarkan pada hasil akhir (result-based performance evaluation); pengukuran didasarkan pada perilaku (behaviour-based performance evaluation); dan pengukuran didasarkan pada penilaian (judgment-Based Performance Evaluation).

Pengukuran didasarkan pada perilaku mengukur cara atau sarana (means) saat proses meraih tujuan, dan tidak mengukur hasil akhir. Pengukuran yang didasarkan perilaku cenderung mengukur aspek

\footnotetext{
Comparing Indian and Japanese Firms," Journal of International Marketing, Vol. 7, No. 4, (1999), 112.

15 J. Singh, W. Verbeke \& G.K. Rhoads, "Do Organizational Practices Matter in Role Stress Processes? A Study of Direct and Moderating Effects for Marketing-Oriented Boundary Spanners," Journal of Marketing, Vol. 60, (1996), 70.

16 Robbins Stephen P. \& Judge Timothy A., Organizational Behavior, 15 th Ed., (Prentice Hall, 2013), 433.
} 
kualitatif, bukan pada aspek kuantitatif. Pengukuran didasarkan pada perilaku cenderung bersifat subjektif, artinya mengasumsikan bahwa kinerja yang efektif bagi diri SDM ataupun untuk rekan kerja SDM bisa diuraikan dengan tepat oleh SDM sendiri. Penelitian-penelitian oleh ilmuwan perilaku organisasi dan sumber daya manusia begitu tertarik pada pengukuran didasarkan perilaku karena terbukti skala pengukuran subjektif memiliki reliabilitas yang kualitasnya sama dengan pengukuran didasarkan hasil. Kelemahan dari model pengukuran seperti ini yaitu berpotensi besar bias pengukuran dikarenakan kinerja diukur dengan dasar persepsi.

Babin dan Boles (1998), ${ }^{17}$ dan Sing et al. $(1996)^{18}$ menjelaskan cara memecahkan masalah tersebut adalah dengan menggunakan instrumen pengukuran kinerja dari beberapa aspek perilaku spesifik, antara lain perilaku inovatif, inisiatif, level potensi diri, manajemen waktu, raihan kuantitas dan kualitas pekerjaan, kapasitas diri untuk meraih tujuan, hubungan dengan rekan kerja serta pelanggan, dan pemahaman atas produk perusahaannya serta produknya pesaing (product knowledge). Metode seperti ini bagi Judge dan Bono (2003) bisa diperuntukkan dalam rangka memecahkan masalah bias pengukuran juga bisa ditujukan untuk mengakomodir aspekaspek kinerja yang sangat luas, sehingga dapat diberikan gambaran job performance yang integratif.

\footnotetext{
17 Babin, B.J. \& J.S. Boles, "Employee Behavior in a Service Environment: A Model and Test of Potential Differences between Men and Women," Journal of Marketing, Vol. 62, (1998), 78.

18 Singh, Verbeke \& Rhoads, "Do organizational Practices.," 75.
}

Penelitian ini mengukur kinerja SDM didasarkan pada kriteria perilaku spesifik dengan mempertimbangkan pengukuran seperti ini telah diperhatikan secara luas dalam penelitian empiris terkait sumber daya manusia serta perilaku organisasi. Penelitian ini menggunakan pengukuran kinerja SDM yang didasarkan kriteria perilaku spesifik melalui media angket antara lain hasil capaian kerja, perilaku inovatif, pengambilan inisiatif, level potensi diri, manajemen waktu, raihan kuantitas dan kualitas pekerjaan, kapasitas diri untuk meraih tujuan, hubungan dengan rekan kerja dan pelanggan, dan pemahaman akan produk perusahaannya serta produknya pesaing. ${ }^{19}$ Semua aspek di atas akan diadaptasikan dengan kondisi pengurus Yayasan Baiturahman yang merupakan subjek penelitian. Pengukuran kinerja yang didasarkan perilaku dapat mengungkap aspek-aspek pekerjaan yang lebih luas sehingga diperoleh gambaran kinerja yang lebih menyeluruh. Dengan demikian manajer bisa menyimpulkan kinerja SDM yang dimiliki secara tepat.

\section{Kepemimpinan Tranformasional}

Dua dasawarsa terahir ini, konsep kepemimpinan transaksional (transactional leadership) dan kepemimpinan transformasional (tranformational leadership) berkembang pesat dan diperhatikan oleh banyak kelompok akademisi maupun praktisi. ${ }^{20}$ Liu et al. ${ }^{21}$

\footnotetext{
19 Ibid., 75.

${ }^{20}$ Locander, Hamilton, Ladik \& Stuart, "Developing a Leadership-rich."

21 W. Liu, D.P. Lepak, R. Takeuchi \& H.P. Sims, "Matching Leadership Styles with Employment Modes: Strategic Human Resource Management
} 
menjelaskan keadaan ini disebabkan dua konsep kepemimpinan itu mampu mewadahi konsep kepemimpinan yang beragam, termasuk meliputi perspektif perilaku, perspektif situasional, sekaligus perspektif kontingensi. Oleh karena itu, penelitian ini menggunakan konsep kepemimpinan transformasional dan transaksional.

Berbeda dengan kepemimpinan transaksional yang didasarkan pada prinsip pertukaran maka kepemimpinan transformasional (transformational leadership) didasarkan pada prinsip pengembangan SDM. Pemimpin yang memiliki perspektif transformasional menganalisis kemampuan dan potensi SDM nya agar saat menjalankan tugas/pekerjaan, sekaligus memperkirakan potensi memperbanyak tanggung jawab dan kewenangan SDM di masa depan.

Humphreys menyatakan bahwa hubungan pimpinan dengan SDM dalam konteks kepemimpinan transformasional tidak hanya sekedar proses bertukar "komoditas" (mempertukarkan imbalan ekonomis), tapi terkait dengan sistem nilai (value system). ${ }^{22}$ Pimpinan yang bersifat transformasional dapat menyatukan semua SDM nya dan dapat merubah keyakinan (beliefs), sikap, dan orientasi pribadi tiap-tiap SDM dalam rangka mencapai tujuan, bahkan melebihi tujuan yang ditetapkan ${ }^{23}$.

Bass et al. $^{24}$ serta Humphreys, ${ }^{25}$ menyampaikan bahwa pemimpin transformasional mampu merubah sistem

Perspective," Human Resource Management Review, Vol. 13, (2003), 127-152.

22 Humphreys, "Transformational Leader Behavior." 23 Ibid. nilai SDM demi meraih tujuan, hal ini didapat dengan menerapkan salah satu atau semua aspek yang tidak lain adalah dimensi kepemimpinan transformasional, yaitu: (a) kharisma (setelahnya berubah menjadi pengaruh ideal atau idealized influence); (b) motivasi inspirasi (inspirational motivation); (c) dorongan intelektual (intellectual stimulation); (d) perhatian pribadi (individualized consideration).

Indikator pimpinan diidentifikasi sebagai pemimpin transformasional bisa diukur pada efek pemimpin terhadap SDM yang dimiliki. SDM seorang pimpinan transformasional merasakan adanya kepercayaan, kekaguman, kesetiaan, serta rasa hormat kepada pemimpin tersebut dan SDM memiliki motivasi untuk berbuat halhal yang melebihi harapan awal pemimpinnya.

Gary A. Yukl dalam Leadership in Organization, ${ }^{26} \quad$ menyampaikan kepemimpinan transformatif memiliki karakter antara lain: (a) fokus dari kepemimpinan transformatif yang pertama mengarah pada kepentingan SDM; (b) pemimpin transformatif berusaha memperhatikan nilai nilai etis; (c) pemimpin transformatif tidak akan menggurui, tetapi mengarahkan SDM untuk berinovasi dan bangkit dari keterpurukannya; (d) kepemimpinan transformatif memiliki nuansa dorongan intelektual.

Kepemimpinan transformatif mengaktifkan dialog antar strata sosial melalui komunikasi

24 Bass, Avolio, Jung \& Berson, "Predicting Unit Performance by Assessing Transformational and Transactional Leadership".

25 Humphreys, "Transformational Leader Behavior."

${ }^{26}$ Gary A. Yukl, "Leadership in Organizations. 2nd Ed.", (New Jersey: Prentice-Hall International, Inc., 1989). 
yang sehat. Dialog ini mengasumsikan ada keterbukaan serta kejelasan visi dari seorang pemimpin ${ }^{27}$. Dengan karakter kepemimpinan transformasional yang seperti di atas, studi ini menghipotesakan kepemimpinan akan mampu memengaruhi kinerja SDM yang dipimpinnya. Dan jika melihat realitas kepemimpinan pada pengurusan baru Yayasan Baiturrahman di tahun 2010 seperti yang dijelaskan di pendahuluan, maka praktak kepemimpinan yang dilakukan lebih dekat kepada kepemimpinan transformasional. Sehingga dalam tulisan ini akan menggunakan kepemimpinan transformasional sebagai dasar membuat angket yang akan diberikan kepada sumber data (para pengurus Baiturrahman).

\section{Kultur Organisasi}

Pada era globalisasi sekarang ini, muncul suatu paradigma yang berupaya mengetahui variabel penjelas yang yang mampu mengungkap bahwa keadaan internal dan eksternal organisasi tidak mudah diprediks atau kondisi normal. Tetapi pada era sekarang faktor - faktor tersebut melainkan pada era sekarang ini faktor-faktor tersebut menjadi amat dinamis, salh satunya faktor SDM. Manusia sebagai mahluk otonom dapat digambarkan oleh variabel penjelas tersebut, dampaknya manusia cenderung dinamis saat berinteraksi di organisasi. Kultur merupakan salah satu yang dipercaya sebagai variabel penjelas. ${ }^{28}$ Perilaku manusia di dalam organisasi dipandang dapat dijelaskan oleh variabel kultur, tentunya dengan asumsi organisasi merupakan suatu kelompok yang memiliki keteraturan pola dan proses interkasi yang berulang. Dalam konteks ini, ada kesamaan antara hubungan interaksi antar manusia pada organisasi dengan di dalam kelompok masyarakat pada umumnya. Dalam dua realitas tersebut terdapat mitos, simbol, norma-norma tidak tertulis, ritual/upacara, dan pahlawan memiliki peran yang tidak jarang lebih kuat dan dipercaya dari pada aturan-aturan formal yang disusun organisasi. ${ }^{29}$ Kultur organisasi dapat dirasakan nilai pentingnya Dengan pemikiran seperti ini, menjadi penting untuk mempelajari kultur organisasi. Secara umum budaya organisasi adalah serangkaian tata nilai, keyakinan, dan pola-pola perilaku yang membentuk identitas organisasi serta perilaku para anggotanya. Salah satu bentuk perilaku anggota organisasi/SDM organisasi yang digerakkan oleh kultur adalah kinerja SDM organisasi tersebut. Dengan demikian isi dari kultur organisasi dan derajat pemahaman dan ketaatan SDM organisasi akan berpengaruh terhadap kinerja SDM organisasi tersebut.

Wilson menjelaskan terkait budaya organisasi dalam dalam konteks perilaku, ${ }^{30}$ adalah kecenderungan pola perilaku yang konsisten, dimana gagasan-gagasan maupun pemikiran-pemikiran diwariskan secara lintas generasi, atau lintas kelompok. Lebih lanjut Wilson menjelaskan bahwa interaksi sosial antar SDM organisasi mengakibatkan transfer perilaku, sehingga hal ini bukan diakibatkan faktor genetik (turun temurun). Pola-pola perilaku

30 A.M. Wilson, "Understanding Organisational Culture and the Implications for Corporate Marketing", European Journal of Marketing, Vol. 35, No. 3/4, (2001), 363. 
tersebut cenderung bersifat tetap dan dapat mengalami perubahan dengan proses yang lamban. Ide-ide atau pemikiran-pemikiran bisa memiliki fungsi sebagai pedoman bagi penerimaan suatu perilaku. Sehingga Pada studi ini, pengukuran budaya organisasinya mendasarkan pada teori Alan M. Wilson, dan menggunakan indikator antara lain pola perilaku pengurus dalam kerjasama dengan pengurus lain, pola perilaku pengurus dalam merespon konflik, pola perilaku pengurus dalam merespon aturan/kebijakan ketua, pandangan pengurus terhadap hasil kerja yang sukses, gambaran manajemen terhadap pengurus yang sukses, kualitas layanan terhadap konsumen, pola perilaku pengurus dalam bekerja (menjalankan program), sesuatu yang menjadi harapan bersama seluruh pengurus, sesuatu yang bisa meredam konflik sesama pengurus sehingga bisa bekerja sama lagi, program prioritas dalam yayasan, dan sesuatu yang menjadi prioritas utama fungsi pengendalian ketua.

Dengan demikian, struktur pengurus baru bisa berdampak pada perubahan budaya organisasi saat bersama pengurus yang lama. Pola kepemimpinan (transformasional) dari Ketua Yayasan Baiturrahman yang memiliki pola interaksi khas pola transformasional dan ada kepedulian pada anggota pengurusnya, maka pola interaksi tersebut mengakibatkan munculnya budaya guyub pada para pengurus dan pengelola unit usaha Yayasan Baiturrahaman.

\section{Hipotesis}

Hipotesis merupakan suatu jawaban yang sifatnya sementara pada rumusan masalah penelitian, hingga data terkumpul dan membuktikan sesuatu. ${ }^{31}$ Didasarkan pada eksplorasi pendapat para ilmuwan dan kerangka teoritik tersebut, maka hipotesis dalam studi ini adalah :

$H_{1}$ : Terdapat pengaruh yang positif dan Ada pengaruh yang positif dan penting / substantif antara Kepemimpinan pada Kinerja SDM Yayasan Baiturrahman Surabaya.

$\mathrm{H}_{2}$ : Terdapat pengaruh positif serta signifikan antara budaya organisasi pada kinerja sumber daya manusia di Yayasan Baiturrahman Surabaya.

$\mathrm{H}_{3}$ : Terdapat pengaruh yang penting / substantif dengan simultan diantara Kepemimpinan serta budaya organisasi pada Kinerja SDM Yayasan Baiturrahman Surabaya.

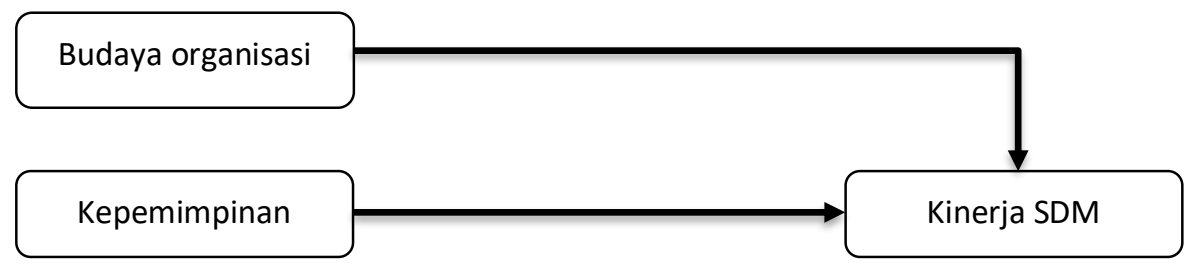

Gambar 1 - Kerangka Pemikiran Teoritis

\footnotetext{
31 Suharsimi Arikunto, Prosedur Penelitian: Suatu Pendekatan Praktek, (Jakarta : Rineka Cipta, 1998), 67.
} 


\section{Metodologi}

Studi ini merupakan studi kuantitatif deskripif, yang sifatnya ex post facto. Studi ini memiliki populasi yang diteliti adalah semua pengurus Yayasan Baiturrahman Surabaya pada tahun 2011, yang berjumlah 25 orang. Sehingga studi ini menjadikan populasi tersebut (yang jumlahnya kecil) menjadi sasaran penelitian, yang biasa disebut penelitian populasi. Berdasarkan eksplorasi pustaka atau pendapat ilmuwan terkait variabel-variabel dalam studi ini, maka bisa disimpulkan definisi operasionalnya antara lain.

Pertama, kinerja sumber daya manusia (SDM) adalah suatu hasil dan proses kerja pengurus yayasan Baiturrahman pada konteks melaksanakan tugas dan wewenangnya dalam rangka mencapai tujuan dengan cara diperbandingkan dengan suatu standar tertentu baik kuantitatif atau kualitatif. Berdasarkan teori yang disampaikan Stephen P. Robbins \& Judge Timothy A., dalam studi ini pengukuran kinerja menggunakan dimensi perilaku pengurus saat melaksanakan tugas, dan kemampuan SDM (pengetahuan dan skill), sedangkan indikator yang digunakan antara lain kualitas hasil kerja, capaian kuantitas hasil kerja, kesesuaian hasil kerja dengan target waktu, keoptimalan dalam bekerja, kesesuaian dengan job desc, kemampuan bekerjasama dengan pengurus lain, penguasaan ketrampilan yang menjadi tuntutan job description (tugas), memiliki/tidak pengetahuan tentang pekerjaannya, memiliki/tidak pengetahuan tentang konsumen, dan memiliki/tidak pengetahuan tentang program organisasi. Secara operasional, studi ini mengadaptasi instrumen yang digunakan pada penelitian Bono \& Judge di tahun 2003.
Kedua, kepemimpinan (tranformasional) merupakan suatu kemampuan atau karakteristik tertentu yang ada pada diri ketua Yayasan dan dianggap lebih dibandingkan pengurus lain dalam yayasan tersebut, hal ini berakibat ketua yayasan memiliki pengaruh pada pengurus lainnya agar berperilaku mengarah pada tercapainya tujuan dengan didasarkan pada prinsip pengembangan dan pengarahan potensi diri SDM. Dalam tulisan ini menggunakan dimensi atau aspek kepemimpinan tranformasional yang dikenalkan oleh Bass \& Avolio yaitu karisma/idealized influence, motivasi inspirasi, pengembangan intelektual, serta perhatian pribadi. Terkait indikator kepemimpinan tranformasional studi ini menggunakan nilai - nilai etis, teladan saat bekerja, punya visi yang jelas terkait organisasinya, bisa memotivasi pengurus yang semangatnya berkurang, mendorong pengurus agar mengembangkan potensi dirinya, mendorong pengurus terus berinovasi pada penyelesaian masalah saat kerja (atau saat menjalankan program organisasi), mengutamakan dialog dalam menyelesaikan masalah di organisasi, dan memperhatikan kesejahteraan pengurus.

Ketiga, budaya organisasi merupakan sekumpulan sistem nilai, keyakinan, dan perilaku terpola yang membentuk jati diri Yayasan Baiturrahman serta pola perbuatan dari pengurusnya. Dalam studi ini pengukuran budaya organisasi menggunakan dimensi karakter organisasi dalam pola interaksi antar pengurus dan dengan manajemen, tolak ukur keberhasilan pengurus, karakteristik umum organisasi, titik berat dalam strategi organisasi dan perekat/ikatan organisasi. Terkait indikator budaya organisasi dalam studi ini adalah: pola perilaku pengurus dalam kerjasama dengan pengurus lain, pola perilaku pengurus dalam merespon konflik, 
pola perilaku pengurus dalam merespon aturan/kebijakan ketua, pandangan pengurus terhadap hasil kerja yang sukses, gambaran manajemen terhadap pengurus yang sukses, kualitas layanan terhadap konsumen, pola perilaku pengurus dalam bekerja (menjalankan program), sesuatu yang menjadi harapan bersama seluruh pengurus, sesuatu yang bisa meredam konflik sesama pengurus sehingga bisa bekerja sama lagi, program prioritas dalam yayasan, dan sesuatu yang menjadi prioritas utama fungsi pengendalian ketua. Sedangkan teknis pengukuran budaya organisasi diukur menggunakan skala likert 1 - 4 .

Metode analisis yang dipakai pada studi ini adalah: (a) uji validitas dan reliabilitas yang bertujuan untuk mengetahui kualitas data; (b) uji asumsi klasik yang menjadi syarat pada analisa regresi berganda agar sesuai dengan kriteria BLUE (Best Linier Unbiased Estimate) seperti yang dijelaskan dalam penelitian Gujarati. ${ }^{32}$ Dalam studi ini menggunakan analisis multikolinearitas, heteroskedastisitas, dan autokorelasi sebagai bentuk uji asumsi klasik; (c) melakukan pengujian hipotesis dalam studi ini dengan model analisa regresi berganda. Model tersebut diwujudkan dalam bentuk persamaan seperti di bawah ini:

$$
Y=a+b_{1} X_{1}+b_{2} X_{2}+e
$$

\section{Keterangan:}

$$
\begin{aligned}
& Y \quad \text { : variabel dependen (kinerja pengurus) } \\
& \begin{array}{l}
a \\
b_{1}, b_{2},
\end{array} b_{3} \text { : konstanta } \\
& X_{1} \quad: \text { kepemisien regresi } \\
& X_{2} \quad \text { : budaya organisasi } \\
& e \quad: \text { kesalahan prediksi (error term) }
\end{aligned}
$$

\footnotetext{
32 D. Gujarati, Basics Econometrics. Fourth Edition,
} (Singapore: McGraw-Hill,2003), 19.
Disamping itu, dalam rangka menguji variabel yang berpengaruh yaitu kepemimpinan $\left(X_{1}\right)$, dan budaya organisasi $\left(X_{2}\right)$ pada kinerja pengurus $(Y)$ maka dilakukan uji t dan uji F. Dan juga koefisien determinasi yang secara substansi menilai seberapa jauh kualitas model persamaan regresi (independent variables) dalam menjelaskan variasi yang terjadi pada variabel terikat.

\section{Profil Responden}

\section{Responden Berdasarkan Jenis Kelamin}

Studi ini menjadikan seluruh pengurus yayasan mulai dari Pembina hingga pelaksana kegiatan menjadi responden, dengan jumlah 25 orang. Sedangkan karakteristik responden didasarkan pada jenis kelamin ternyata masih didominasi pengurus berjenis kelamin laki-laki, hal ini dapat kita lihat didalam tabel sebagai berikut:

Tabel 2 - Responden Didasarkan pada Jenis Kelamin

\begin{tabular}{c|c|c|c}
\hline No & Jenis Kelamin & Frekuensi & Persentase \\
\hline 1 & Laki-Laki & 21 & $84 \%$ \\
2 & Perempuan & 4 & $16 \%$ \\
\hline \multicolumn{2}{r|}{ Jumlah } & 25 & $100 \%$ \\
\hline
\end{tabular}

\section{Responden Didasarkan pada Tingkat}

\section{Pendidikan}

Dalam hal tingkat pendidikan, pengurus Yayasan ternyata cukup variatif, terdiri dari lulusan SLTA, S1, S2, hingga S3. Karakteristik responden didasarkan pada tingkat 
pendidikan bisa dilihat dalam tabel berikut ini:

Tabel 3 - Responden Berdasarkan Tingkat Pendidikan

\begin{tabular}{c|l|c|c}
\hline No & $\begin{array}{c}\text { Tingkat } \\
\text { Pendidikan }\end{array}$ & Frekuensi & Persentase \\
\hline 1 & SLTA & 6 & $24 \%$ \\
2 & Sarjana (S1) & 16 & $64 \%$ \\
3 & $\begin{array}{l}\text { Pasca } \\
\text { Sarjana }\end{array}$ & 3 & $12 \%$ \\
\hline \multicolumn{2}{|c|}{ Jumlah } & $\mathbf{2 5}$ & $\mathbf{1 0 0 \%}$ \\
\hline
\end{tabular}

\section{Responden Berdasarkan Pengalaman}

Karakteristik pengurus yayasan berdasarkan pengalamannya di yayasan ini ternyata ada variasi juga. Ada yang menjadi pengurus yayasan pada tahun 2010 dan ada pula yang sudah sudah lama bergabung pada Yayasan Baiturrahman. Karakteristik ini dideskripsikan pada tabel berikut ini:

Tabel 4 - Responden Berdasarkan Pengalaman

\begin{tabular}{c|c|c|c}
\hline No & Pengalaman & Frekuensi & Persentase \\
\hline 1 & Baru & 7 & $28 \%$ \\
2 & Lama & 18 & $72 \%$ \\
\hline \multicolumn{2}{c|}{ Jumlah } & $\mathbf{2 5}$ & $\mathbf{1 0 0 \%}$ \\
\hline
\end{tabular}

\section{Responden Berdasarkan Status} Perkawinan

Berdasarkan status perkawinan, semua pengurus Yayasan telah menjalani pernikahan (100\%). Dengan karakter seluruh pengurus sudah menikah maka harapannya bisa mendorong perilaku yang lebih bijak dan bertanggung jawab. Potensi kemajuan Yayasan Baiturrahman makin besar.

33 Yus Agusyana, Olah Data Skripsi dan Penelitian dengan SPSS 19, (Jakarta : PT. Elex Media Komputindo, 2011), 39.

\section{Hasil Pengujian Instrumen}

Dalam studi ini dilakukan pengukuran reliabilitas yang ditujukan untuk mengetahui sejauh mana kesesuaian hasil jika dilakuakn dua kali pengukuran atau lebih dengan alat ukur yang berbeda. Metode yang digunakan dalam studi ini untuk mengukur reliabilitas instrumennya dengan menggunakan teknik Cronbach Alpha $^{33}$. Hasil uji pada variabel operasional studi ini adalah nilai Cronbach Alpha variabel Kinerja SDM sebesar 0,721; Kepemimpinan sebesar 0,740; dan Budaya Organisasi sebesar 0,747. Nilai cronbach alpha dari ketiga variabel, masing - masing lebih besar dari 0,66, maka instrumen dan datanya dinyatakan reliabel. ${ }^{34}$

Selain itu, pada pengukuran validitas dalam studi ini menggunakan jenis uji validitas konstruk dengan mengukur nilai korelasi beberapa variabel yang menurut teori mengukur hal yang sama. ${ }^{35}$ Pengukuran validitas data menggunakan software SPSS (Statistical Pacgkage for Social Scince) yang memperoleh hasil bahwa nilai probabilitas cukup signifikan pada sebagian besar instrumen yaitu lebih kecil dari 0,05 ( $\alpha=5 \%$ ). Hal ini menunjukkan korelasi yang signifikan pada sebagian besar instrumen dari setiap variabel, dan itu berarti sebagian besar instrumen menunjukkan validitas tinggi. Validitas instrumen ini tidak berlaku pada beberapa instrumen yang memiliki nilai probabilitas signifikan yang lebih besar dari 0,05 , hal ini berarti beberapa instrumen itu tidak valid. Instrumen tersebut (P30, P31, P20, P5, dan K11) tidak digunakan dalam

\footnotetext{
34 Riduwan, Metode \& Teknik Menyusun Tesis, (Bandung: Alfabeta, 2010), 128.

35 Saifuddin Azwar, Reliabilitas \& Validitas, (Yogyakarta: PT. Pustaka Pelajar, 2001), 50.
} 
studi ini di tahap analisis lebih lanjut. Didasarkan hasil pengujian validitas dan reliabilitas data yang dijelaskan di atas, maka proses analisa lebih lanjut dalam rangka menguji hipotesis dapat diteruskan.

Selanjutnya dilakukan pengukuran normalitas data yang berfungsi untuk mengidentifikasi adanya distribusi yang normal dalam data yang terkumpul. Pengujian ini bermanfaat untuk menentukan teknik statistik apa yang akan digunakan saat uji statistika berikutnya (jenis uji Statistik Inferensial). Uji Kolmogorov Smirnov yang dipilih untuk melakukan uji normalitas dengan bantuan software SPSS memperolah hasil nilai signifikan variabel kinerja SDM adalah 0,217 ; sedangkan variabel kepemimpinan adalah 0,494; serta variabel budaya organisasi adalah 0,538 . Dari hasil itu dapat diketahui bahwa nilai sig. dari semua variabel setelah dilakukan uji normalitas dengan Kolomogorov Smirnov lebih besar dari 0,05. Dengan demikian dapat diartikan bahwa ketiga variabel diatas memiliki distribusi normal.

Setelah itu penulis melakukan uji multikolinieritas yang berfungsi menguji apa dalam model regresi akan ditemui ada hubungan kuat antar variabel independen. Nilai VIF pada studi ini bahwa tolerance seluruh variabel lebih besar dari 0,1 (kepemimpinan memiliki nilai 0,568, dan budaya organisasi memiliki nilai 0,568) serta nilai VIF dari dua variabel independen tersebut kurang dari 10 (kepemimpinan sebesar 1,759, dan budaya organisasi sebesar 1,759) bahkan mendekati angka 1. Hal ini memiliki arti pada kedua variabel independen tersebut tidak terdapat multikolinieritas. Berdasarkan hasil uji multikolinieritas dapat diartikan bahwa tidak terdapat hubungan kuat antar dua variabel independen yaitu kepemimpinan serta budaya organisasi. Jika terjadi hubungan yang kuat di antara keduanya maka akan memengaruhi pola hubungan antar tiga variabel, sehingga tidak bisa lagi menggunakan uji regresi linier berganda. Dikarenakan tidak ada hubungan kuat antar dua variabel independen (kepemimpinan dan budaya organisasi) pada kepengurusan Yayasan Baiturrahman, maka setelah ini dapat dilakukan uji regresi linier berganda.

Selanjutnya dilakukan uji autokorelasi yang berfungsi mengidentifikasi hubungan (korelasi) antar anggota observasi yang ditata berdasarkan waktu (time series) atau ruang (cross section). ${ }^{36}$ Implikasi jika diidentifikasi ada autokorelasi dalam suatu model regresi maka variasi sampel menjadi tidak bisa memberikan gambaran variasi populasinya. Hal itu berdampak pada model regresi yang dirumuskan tidak bisa dipakai memperkirakan nilai variabel dependen pada variabel indenpenden itu. Dalam rangka mengidentifikasi masalah autokorelasi dari suatu model regresi, akan dilihat dari indikator Durbin-Watson (DW), nilai DW tabelnya pada tingkat $\alpha=5 \%$ dengan $\mathrm{n}=25$ dan $\mathrm{k}=2$ adalah batas bawah ( $\mathrm{dl}=1,206)$ dan batas atas ( $\mathrm{du}=$ 1,549) seperti penjelasan pada bab III terkait rumusan daerah bebas autokorelasi antara lain du < DW $<4-$ du = bebas Autokorelasi. Jika nilai batas atas dan batas bawahnya dimasukkan ke persamaan di atas, maka hasilnya adalah daerah bebas autokorelasi berada dalam interval 1,549 $<\mathrm{DW}<2,451$. $\mathrm{Di}$

\footnotetext{
${ }^{36}$ Gujarati, Basics Econometrics., 38.
} 
lain sisi diketahui bahwa nilai DW $=2,082$; Dengan demikian bisa disimpulkan bahwa model regresi tidak mempunyai gejala autokorelasi.

Pengujian selanjutnya adalah uji heteroskedastisitas yang diukur dengan cara Uji Glejser, persamaan uji glejser dapat dilihat di bawah ini.

$$
|e|=b 1+b_{2} X_{2}+v
$$

\section{Keterangan:}

| e | : nilai absolut dari residual hasil regresi model

$X_{2} \quad$ :variabel penjelas

Uji glejser yang dilakukan dalam studi ini memanfaatkan software SPSS 16, jika ditemukan ada pengaruh variabel penjelas terhadap residual maka dapat dipastikan model ini mempunyai masalah heterokedastisitas.

Hasil pengujian heteroskedastisitas dalam studi ini adalah nilai signifikansi variabel kepemimpinan sebesar 0,054, dan variabel budaya organisasi sebesar 0,076 ; keduanya lebih besar dari 0,05 ( $\alpha=5 \%)$ artinya tidak signifikan, sehingga bisa disimpulkan model regresi dalam studi ini tidak terdapat gejala heteroskedastisitas. Terjadinya heteroskedastisitas berdampak nilai-nilai estimator koefisien regresi tidak efektif meskipun estimator tersebut tidak bias dan konsisten; sehingga jika hasil pengujian ini tidak terdapat gejala heteroskedastisitas, maka nilai-nilai estimator koefisien regresi akan efektif. Dengan demikian dapat disimpulkan persamaan regresi pada tiga variabel yaitu kepemimpinan, budaya organisasi serta kinerja SDM dapat memperkirakan secara efektif mendekati kenyataannya.
Jadi pengukuran asumsi klasik yang diterapkan pada persamaan regresi dalam studi ini dapat disimpulkan bahwa persamaan regresinya dapat digunakan sebagai model persamaan matematis. Setelah itu pengujian yang diperlukan adalah pengujian hipotesis penelitian yaitu uji $\mathrm{F}$ dan uji t. Hasil dari pengujian tersebut dapat diketahui ada tidaknya pengaruh variabel independen dengan variabel dependen.

Pengujian yang dilakukan bersamaan ditempuh dengan menggunakan uji $F$, yaitu dengan membandingkan nilai $F_{\text {hit }}$ dengan $F_{\text {tabel, jika }} F_{\text {hit }}>F_{\text {tabel }}$ atau nilai probabilitas signifikansi lebih kecil dari tingkat alfa yang dipilih maka variabel independent secara bersamaan berpengaruh pada variabel dependent. Dalam studi ini Uji F dan Uji t dilakukan dengan bantuan SPSS 16 . Berdasarkan hasil Uji $\mathrm{F}$ dan Uji $\mathrm{t}$ dapat disusun suatu model persamaan regresi berganda, nilai beta didapatkan dari unstandarized coefficient, model persamaannya seperti di bawah ini :

$Y=29,138+0,760 X_{1}-0,314 X_{2}+0,251$

\section{Keterangan:}

\section{$Y$ : Kinerja SDM}

$X 1$ : Kepemimpinan

X2 : Budaya Organisasi

Hasil model persamaan di atas menunjukkan bahwa satu dari dua variabel bebas terdapat nilai koefisien regresi negatif yaitu variabel budaya organisasi. Sedangkan variabel Kepemimpinan memiliki tanda positif. Pada kondisi seperti ini nilai koefisien dari tiap - tiap variabel tidak dapat diinterpretasi sebagai elastisitas mengingat variabel persamaan regresinya bukan dalam 
bentuk logaritma ${ }^{37}$. Sehingga uji parsial pada penelitian ini hanya diidentifikasi dari tandanya saja. Variabel dependennya (kinerja SDM) dipengaruhi cukup signifikan secara parsial (uji t) oleh seluruh variabel bebasnya. Secara umum model ini nampak sudah layak atau berkulitas baik dikarenakan nilai uji $\mathrm{F}$ nya adalah signifikan dengan probabilitas 0,000 dan nilai koefisien determinasinya sebesar 0,749 artinya $74,9 \%$ variasi pada aspek Kinerja SDM pengurus Yayasan Baiturrahman Surabaya bisa dijelaskan oleh Kepemimpinan (X1), serta Budaya
Organisasi $\left(\mathrm{X}_{2}\right)$, baru kemudian sisanya sebesar 25,1\% dijelaskan variabel lain di luar model persamaan regresi tersebut.

\section{Hasil Pengujian Hipotesis}

\section{Hipotesis Pertama}

$\mathrm{H}_{1}$ : Terdapat pengaruh yang positif dan Ada pengaruh yang positif dan penting / substantif antara Kepemimpinan pada Kinerja SDM Yayasan Baiturrahman Surabaya.

Studi ini menghasilkan temuan antara lain:

Tabel 5 - Rangkuman Hasil Output Regresi

\begin{tabular}{|l|c|c|c|}
\hline \multicolumn{4}{|c|}{ Variabel Dependen = Kinerja SDM $(\mathrm{Y})$} \\
\hline $\begin{array}{c}\text { Variabel Indp. Koef. } \\
\text { Regresi t }\end{array}$ & ratio Prob. Sig. & $\begin{array}{c}\text { Variabel Indp. Koef. } \\
\text { Regresi t }\end{array}$ & ratio Prob. Sig. \\
\hline Kepemimpinan $\left(\mathrm{X}_{1}\right)$ & 0,760 & 7,566 & $0,000^{* *}$ \\
\hline Budaya Org. $\left(\mathrm{X}_{2}\right)$ & $-0,314$ & $-2,805$ & $0,010^{* *}$ \\
\hline Konstanta & 29,138 & 4,412 & $0,000^{* *}$ \\
\hline $\mathrm{R}^{2}=0,749$ & & \\
F-Ratio $=32,740$ & & \\
Prob.Sig $=0,000^{* *}$ & & \\
$\Sigma$ Var.Indep. Signifikan = 2 dari 2 & \\
$\mathrm{DW}=2,082$ (Bebas Autokorelasi) & \\
$\mathrm{N}=25$ & & \\
\hline
\end{tabular}

Sumber: Output Estimasi Regresi.

Pada tabel tersebut bisa dilihat nilai t hitung dari variabel $X_{1}$ memiliki probability significancy $(0,000)$ lebih kecil $0,05(\alpha=5 \%)$, jadi $\mathrm{H}_{0}$ ditolak atau $\mathrm{H}_{1}$ diterima, maka bisa disimpulkan variabel kepemimpinan berpengaruh secara positif dan signifikan terhadap variabel Kinerja SDM pengurus Yayasan Baiturrahman Surabaya. Hasil tersebut memiliki makna makin baik kepemimpinan dalam kepengurusan
Yayasan Baiturrahman Surabaya dapat berakibat peningkatan kinerja SDM pengurus yayasan tersebut. Dan juga dapat berarti kebalikannya, jika Kepemimpinan dalam kepengurusan yayasan tidak sesuai ataupun tidak kondusif dapat berakibat menurunkan kinerja SDM pengurusnya. Maka bisa disimpulkan hipotesis terkait adanya pengaruh yang positif dan signifikan antara variabel kepemimpinan dan variabel

37 Ibid., 43. 
kinerja SDM pengurus Yayasan Baiturrahman Surabaya bisa diterima. Hal ini sebagai pertanda bahwa penerapan pola kepemimpinan transformasional pengurus baru, dapat mempunyai pengaruh positif dan signifikan bagi hasil dan proses kerja (kinerja) para pengurus Yayasan tersebut. Jika dihubungkan dengan penjelasan Bass et al. $^{38}$ serta Humphreys ${ }^{39}$ bahwa dimensi kepemimpinan transformasional yang terdiri dari kharisma, motivasi inspirasi, pengembangan intelektual, dan perhatian pribadi ternyata memang benar benar terbukti secara empiris pada pengurus Baiturrahman memiliki efek positif dan signifikan terhadap kinerja pengurus Yayasan Baiturrahman, baik itu terhadap hasil kerja maupun proses kerjanya.

\section{Hipotesis Kedua}

$\mathrm{H}_{2}$ : terdapat pengaruh positif serta signifikan antara budaya organisasi pada kinerja sumber daya manusia di Yayasan Baiturrahman Surabaya.

Dalam analisis sebelum ini dapat dilihat besarnya nilai $\mathrm{t}$ hitung dari variabel $\mathrm{X}_{2}$ memiliki probability significancy $(0,010)$ lebih kecil 0,05 atau mendekati nol dan nilai ratio Probabilitas Signifikan variabel $X_{2}$ (budaya organisasi) bernilai -0,314, hal ini dapat diartikan bahwa variabel budaya organisasi memiliki pengaruh negatif dan signifikan pada variabel kinerja SDM pengurus. Hal ini berimplikasi $\mathrm{H}_{2}$ ditolak karena pengaruh budaya organisasi meskipun signifikan namun memiliki nilai negatif terhadap kinerja SDM kepengurusan Yayasan ini.

Makna empirik pada temuan di hipotesis kedua ini adalah suatu perubahan di budaya

38 Bass, Avolio, Jung \& Berson, "Predicting Unit Performance." organisasi dapat berpengaruh pada Kinerja SDM pengurus Yayasan Baiturrahman Surabaya. Makin SDM pengurus merasakan kuatnya budaya pada kepengurusan Yayasan Baiturrahman Surabaya berimplikasi makin turunnya kinerja SDM pengurusnya. Analisis erhadap hal ini jika dikaitkan kondisi empiris khususnya budaya yang dominan di kalangan SDM Pengurus Yayasan Baiturrahman Surabaya yaitu cenderung pada nilai-nilai guyub, kurang bisa menerima konflik dalam bentuk apapun (termasuk kompetisi). Pada hasil studi ini nilai - nilai guyub dianggap budaya organisasi oleh sebagian besar SDM Pengurus Baiturrahman Surabaya dan ternyata makin kuat budaya itu maka dapat berimplikasi makin menurunkan kinerja SDM Pengurus Yayasan Baiturrahman. Jadi konteks budaya organisasi seperti ini yang membuat hasil hipotesis kedua menjadi negatif serta memiliki pengaruh signifikan. Dengan demikian Hipotesis kedua yang menyatakan Ada pengaruh positif dan signifikan antara budaya organisasi dan kinerja SDM Pengurus Yayasan Baiturrahman Surabaya menjadi ditolak. Jika dikaitkan dengan teori budaya organisasi, bahwa budaya organisasi akan memengaruhi pemahaman dan ketaatan individu-individu didalam organisasi terhadap norma-norma organisasinya, yang kemudian norma norma tersebut akan memengaruhi perilaku sdm tersebut termsuk perilaku mereka saat melaksanakan tugas-tugas organisasi. Sehingga tingkat pemahaman dan ketaatan sumber daya manusia organisasi berpengaruh signifikan terhadap proses dan hasil kerja SDM organisasi, tetapi arah pengaruhnya ditentukan oleh isi budaya

\footnotetext{
39 Humphreys, "Transformational Leader Behavior."
} 
yang ada atau dominan dalam organisasi tersebut. Jika budaya tersebut berdampak melemahkan kinerja, maka akan berpengaruh negatif terhadap kinerja sdm.

\section{Hipotesis Ketiga}

$\mathrm{H}_{3}$ : Terdapat pengaruh yang penting/ substantif dengan simultan diantara Kepemimpinan serta budaya organisasi pada Kinerja SDM Yayasan Baiturrahman Surabaya

Berdasarkan pengujian $F$ yang sudah dilakukan dalam studi ini, dapat dihasilkan nilai $F$ hitung dari variabel $X_{1}$ dan $X_{2}$ memiliki probability significancy $(0,000)$ yang ini memiliki nilai lebih kecil 0,05 ( $\alpha=5 \%$ ) maka $\mathrm{H}_{0}$ ditolak atau dengan kata lain $\mathrm{H}_{3}$ diterima, disamping itu terdapat temuan di tabel bahwa besar koefisien determinasinya adalah 0,749; hal ini memiliki makna 74,9\% variasi variabel kinerja SDM pengurus Yayasan Baiturrahman Surabaya dapat dijelaskan oleh kepemimpinan (X1), dan budaya organisasi $\left(\mathrm{X}_{2}\right)$, sedangkan sisanya senilai $25,1 \%$ dijelaskan variabel lain di luar model persamaan regresi linier tersebut. Jadi bisa disimpulkan bahwa variabel kepemimpinan (transformasi) dan budaya organisasi memiliki pengaruh signifikan secara simultan terhadap variabel kinerja SDM pengurus Yayasan Baiturrahman Surabaya. Hal ini memiliki makna perubahan pada variabel kepemimpinan (transformasional) dan budaya organisasi akan berpengaruh signifikan secara simultan terhadap Kinerja SDM. Maka hipotesis yang menjelaskan ada pengaruh signifikan secara simultan antara Kepemimpinan (transformasional) dan budaya organisasi pada kinerja SDM pengurus Yayasan Baiturrahman Surabaya dapat diterima. Hal ini memiliki kesesuaian bahkan bisa memberikan tambahan kesimpulan pada penelitian sebelumnya yang merupakan hasil penelitian Humpreys serta Desphande \& Farley yang menjelaskan adanya hubungan kepemimpinan transformasional dengan kinerja dan hubungan budaya organisasi dengan kinerja SDM-nya.

\section{Kesimpulan}

Didasarkan pada analisa regresi berganda pada studi ini, maka bisa disimpulkan ada pengaruh positif dan signifikan antara kepemimpinan serta kinerja SDM pengurus Yayasan Baiturrahman Surabaya yang memiliki nilai t hitung sebesar 7,566 dengan probabilitas $0,000<0,05$; maka bisa dinyatakan variabel Kepemimpinan memiliki pengaruh positif dan signifikan pada variabel kinerja SDM pengurus Yayasan Baiturrahman Surabaya. Sehingga hipotesis pertama yang menjelaskan terdapat pengaruh positif dan signifikan antara kepemimpinan serta kinerja SDM pengurus Yayasan Baiturrahman Surabaya bisa diterima.

Disamping itu ada pengaruh signifikan antara budaya organisasi pada kinerja SDM pengurus Yayasan Baiturrahman Surabaya, yaitu diketahui nilai t hitung sebesar $-2,805$ dengan probabilitas $-0,010<0.05$ (tingkat kepercayaan $\alpha=5 \%$ ) maka bisa dinyatakan variabel budaya organisasi mempengaruhi secara negatif dan signifikan pada variabel kinerja SDM Pengurus Yayasan Baiturrahman Surabaya. Sehingga bisa disimpulkan hipotesis kedua yang menjelaskan bahwa terdapat pengaruh yang positif dan signifikan antara budaya organisasi dan kinerja SDM Pengurus Yayasan Baiturrahman Surabaya tidak dapat diterima. 
Selain itu juga ada pengaruh yang signifikan antara kepemimpinan dan budaya organisasi pada kinerja SDM pengurus Yayasan Baiturrahman Surabaya yang mana didapatkan nilai uji $\mathrm{F}$ nya adalah signifikan dengan probabilitas 0,000 dan besar koefisien determinasinya adalah 0,749 ; hal ini memiliki makna $74,9 \%$ variasi variabel kinerja SDM pengurus Yayasan Baiturrahman Surabaya dapat dijelaskan oleh kepemimpinan (X1), dan budaya organisasi $\left(\mathrm{X}_{2}\right)$, sedangkan sisanya sebesar $25,1 \%$ diterangkan variabel lain diluar model.

Dalam studi ini terdapat beberapa celah yang bisa diperbaiki dalam studi berikutnya yang sejenis, antara lain banyaknya subjek penelitian yang hanya 25 orang (populasi) serta masih ada $35,1 \%$ pengaruh dari faktor selain kepemimpinan dan budaya organisasi pada kinerja SDM organisasi. Sehingga saran bagi studi berikutnya ada dua hal untuk lebih menyempurnakan hasil studi ini adalah memilih subjek penelitian yang populasinya berjumlah lebih banyak dari 25 orang serta memberikan tambahan variabel dependennya tidak hanya kepemimpinan dan budaya organisasi, namun bisa variabel lain pada manajemen organisasi yang diperkirakan secara teori ataupun hasil penelitian lain memiliki hubungan dengan kinerja SDM. Sedangkan saran studi ini untuk organisasi dakwah, bahwa dalam meningkatkan kinerja organisasi perlu memerhatikan bukan hanya aspek kepemimpinan tetapi aspek budaya organisasi, terutama perlu selektif terhadap jenis budaya yang berkembang di organisasi harus mendukung kinerja organisasi secara positif.

\section{Bibliografi}

Agusyana, Yus. Olah data Skripsi dan Penelitian dengan SPSS 19. Jakarta: PT. Elex Media Komputindo, 2011.

Arikunto, Suharsimi. Prosedur Penelitian: Suatu Pendekatan Praktik. Jakarta : Rineka Cipta, 1998. Azwar, Saifuddin. Reliabilitas \& Validitas. Yogyakarta: PT. Pustaka Pelajar, 2001.

Bass, B.M., B.J. Avolio, D.I. Jung \& Y. Berson. "Predicting Unit Performance by Assessing Transformational and Transactional Leadership" Journal of Applied Psychology, Vol. 88, 2003.

Dharma, Surya. Manajemen Kinerja (Falsafah Teori dan Penerapannya). Yogyakarta: Pustaka Pelajar, 2009.

Dvir, T., D. Eden, B.J. Avolio \& B. Shamir. "Impact of Transformational Leadership on Follower Development and Performance: A Field Experiment" Academy of Management Journal, Vol. 45, 2002.

D. Gujarati. Basics Econometrics, Fourth Edition. Singapore: McGraw-Hill, 2003.

Gibson, Ivancevich, dan Donnelly. Organizations: Organisasi, Perilaku, Struktur, Proses. Diterjemahkan Nunuk Ardiani. Jakarta: Penerbit Binarupa Aksara, 1996.

Harber, D.G., N.M. Ashkanasy \& V.J. Callan. "Implementing Quality Service in a Public Hospital Setting: A Path-Analytic Study of the Organizational Antecedents of Employee Perceptions and Outcomes" Public Productivity \& Management Review, Vol. 21, 1997. 
Humphreys, J.H. "Transformational Leader Behavior, Proximity and Successful Services Marketing" Journal of Services Marketing, Vol. 16, 2002.

Locander, W.B., F. Hamilton, D. Ladik \& J. Stuart. "Developing a Leadership-Rich Culture: The Missing Link to Creating a Market-Focused Organization" Journal of Market-Focused Management, Vol. 5, 2002.

Riduwan. Metode \& Teknik Menyusun Tesis. Bandung: Alfabeta, 2010.

Robbins, Stephen P. \& Timothy A. Judge. Organizational Behavior, 15 th Ed. New Jersey: Prentice-Hall International, 2013.

Yammarino, F.J., W.D. Spangler \& B.M. Bass. "Transformational Leadership and Performance: A Longitudinal Investigation" Leadership Quarterly, Vol. 4, 1993. 